\title{
Dualisme Kompetensi Peradilan Permohonan Pengangkatan Anak Bagi Pemohon Yang Beragama Islam
}

\section{Nugroho Noto Diharjo}

Institut Agama Islam Negeri Ponorogo

nugrohonotodiharjo@gmail.com

Abstract: The Child adoption application for Moslem applicants and Moslem adopted children potential are legal by the State court and the religion court in pratice, for this reason this matter causes the competency dualism in accepting, examining, and assigning that child adoption application. in the Mojokerto state court Decicion No.04/Pdt P/2012//PN Mkt, the Purwokerto faith courtroom Desicion No.a hundred thirty/Pdt P/2014/PA Pwt. the ones fourt courtsstate that they are legal to accept, examine and assign the adoption of children. according to the research, by way of yuridis normative approch sesult of the child adoption application proposed by means of Moslem applicants, both in the religion court and trough the state court have the authority to just accept, have a look at, grant, and assign the child adoption application, but with different legal consideration. inside the state court decision, the judicial legal consideration refers back to the common legislation law such as the child Protrction laws, the population Administrations law, the Goverment Ordinance, and the supreme court circular, however, the religious court in based on the Islamic law compilation. The legal consequences caused by child adoption decision carried out inside the state court, the adopted kids have inheritance rights from the adoptive mother and father, at the same time as in the religious Courts, the adoyed children do not server ties with the biological parents. consequently the adopted children do not inherit property from the adoptive mother and father.

Keywords: authorization dualism, child adoption, different legal consequence 
Dualisme Kompetensi Peradilan Permohonan Pengangkatan Anak Bagi Pemohon Yang Beragama Islam

\section{LATAR BELAKANG}

Sesuai ketentuan Pasal 1 ayat (3) Undang-Undang Dasar 1945 Indonesia merupakan Negara berdasarkan atas hukum. Dimana salah satu ciri negara hukum ialah adanya system peradilan yang bebas dari tekanan kekuasaan di luar kekuasaan kehakiman. Dalam Pasal 18 Undang-Undang No. 48 Tahun 2009 tentang Kekuasaan Kehakiman dinyatakan bahwa Kekuasaan Kehakiman dilakukan oleh sebuah Mahkamah Agung dan badan-badan peradilan di bawahnya dalam lingkungan peradilan umum, lingkungan peradilan agama, lingkungan peradilan militer dan lingkungan peradilan tata usaha negara dan oleh sebuah Mahkamah Konstitusi.

Dari setiap lembaga-lembaga peradilan tersebut mempunyai kewenangan khusus yang sering disebut kompetensi absolut. Kompetensi absolut yang disebut adalah semua ketentuan tentang apa yang ada dalam kekuasaan suatu lembaga peradilan. Kewenangan ini didasarkan pada undang-undang yang mengaturnya. Kewenangan Peradilan Umum diatur dalam Undang-Undang No. 2 Tahun 1986 Tentang Peradilan Umum sebagaimana diubah dengan UndangUndang No. 8 Tahun 2004 dan diubah lagi dengan Undang-Undang No. 49 Tahun 2009.

Pasal 2 Undang-Undang No. 2 Tahun 1986 menyebutkan "Peradilan merupakan pelaksana kekuasaan kehakiman bagi rakyat pencari keadilan pada umumnya". Dalam penjelasan Pasal 2 dikemukakan "disamping peradilan yang berlaku bagi rakyat pencari keadilan pada umumnya mengenai perkara perdata dan pidana, ada pelaksanaan kekuasaan kehakiman lain yang merupakan peradilan khusus bagi golongan rakyat tertentu atau perkara tertentu, yaitu Peradilan Agama, Peradilan Militer dan Peradilan Tata Usaha Negara.

Perkara perdata adalah perkara hukum yang mengatur hubungan antara perseorangan yang satu dengan perseorangan yang lain, yang menimbulkan hak dan kewajiban. Secara historis hukum perdata yang berlaku di Indonesia bersifat majemuk, karena 
didasarkan pada hukum adat, hukum Islam dan Kitab UndangUndang Hukum Perdata. Hal tersebut dapat dipahami karena saat itu Pemerintahan Hindia Belanda memberlakukan pembagian 3 (tiga) golongan berdasarkan Pasal 131 jo Pasal 163 IS, golongan Eropa, golongan Bumiputra dan golongan Timur Asing, yang membawa akibat pada kewenangan peradilan dan hukum yang digunakan untuk menyelesaikan perkara perdata saat itu.

Sengketa perdata di Pengadilan Negeri dimulai dengan adanya tuntutan hak dari pihak yang dirugikan dengan cara mengajukan gugatan, di sini sedikitnya ada dua pihak, peradilannya disebut peradilan contenteus dan peradilan voluntair untuk memeriksa perkara yang oleh undang-undang ditentukan harus melalui pengajuan permohonan. ${ }^{1}$

Salah satu bentuk permohonan yang oleh undang-undang ditentukan melalui pengajuan permohonan ke pengadilan adalah perkara pengangkatan anak. Kewenangan untuk memeriksa dan mengadili perkara permohonan pengangkatan anak, khususnya yang beragama Islam, di dalam prakteknya dilakukan oleh Pengadilan Negeri dan Pengadilan Agama.

Undang-Undang No. 3 Tahun 2006 tentang Peradilan Agama memberikan kewenangan kepada Pengadilan Agama untuk mengadili permohonan pengangkatan anak berdasarkan kepada hukum Islam. Akan tetapi, undang-undang tersebut tidak menghapus kewenangan Pengadilan Negeri untuk mengadili perkara permohonan pengangkatan anak bagi yang beragama Islam. Selama ini perkara permohonan pengangkatan anak menjadi kewenangan absolut Pengadilan Negeri dengan hukum terapan Staatblad No. 129 Tahun 2017 yang nilai filosofinyaberasal dari budaya masyarakat keturunan Tionghoa sehingga membawa konsekuensi hukum yang sangat bertentangan dengan hukum Islam.

1Sudikno Mertokusumo, 2010, Hukum Acara Perdata, Yogyakarta, Liberty, h.5. 
Oleh sebab itu, umat Islam menuntut melaluilembaga legislatif agar diberikan jalan hukum untuk mengajukan permohonan pengangkatan anak berdasarkan hukum Islam. Maka, pada tanggal 20 April 2006 lahirlah Undang-Undang No. 3 Tahun 2006 tentang Perubahan atas Undang-Undang No. 7 Tahun 1989 Tentang Peradilan Agama yang memberikan kewenangan absolut kepada Pengadilan Agama untuk menerima, memeriksa dan mengadili serta menyelesaikan perkara "asal usul anak dan pengangkatan anak berdasarkan hukum Islam". ${ }^{2}$ Pedoman Teknis Administrasi dan Teknis Peradilan Perdata Umumdan Perdata Khusus Buku II Edisi 2007 yang diterbitkan Mahkamah Agung tahun 2009 dalam alinea angka 7 mengatur bahwa permohonan pengangkatan anak ditujukan kepada Pengadilan Negeri yang daerah hukumnya meliputi tempat tinggal anak yang hendak diangkat.

Kompetensi absolut Pengadilan Negeri dan Pengadilan Agama ternyata memiliki kesamaan dalam menangani perkara permohonan pengangkatan anak yang diajukan oleh pemohon yang beragama Islam. Artinya baik Pengadilan Negeri maupun Pengadilan Agama sama-sama memiliki kewenangan untuk menerima, memeriksa dan menetapkan pengangkatan anak,sehingga terjadi dualisme kompetensi kewenangan.

Bila kedua belah pihak tidak menyadari atau tidak mengetahui mengenai kewenangan sebuah Pengadilan maka dalam pemeriksaan, seorang hakim diberikan wewenang secara $e x$ officio untuk menyatakan pengadilan tersebut tidak berwenang meskipun tidak ada eksepsi dari Tergugat. ${ }^{5}$ Begitu detailnya pengaturan mengenai kewenangan absolut tersebut dimaksudkan untuk menghindari kekacauan atau ketidakpastian hukum bagi pencari keadilan oleh karenanya yahya harahap menyebut

${ }^{2} \mathrm{HM}$ Fauzan, "Perbedaan Mendasar Akibat Hukum Penetapan Pengangkatan Anak Pengadilan Negeri dan Pengadilan Agama", Jurnal Varia Peradilan, Jakarta, Tahun XXII No.256 Maret 2007, h. 33. 
Dualisme Kompetensi Peradilan Permohonan Pengangkatan Anak Bagi Pemohon Yang Beragama Islam

kewenangan absolut adalah termasuk public order (kepentingan umum) ${ }^{3}$

Berdasarkan ketentuan dan pedoman tersebut permohonan pengangkatan anak bagi pemohon yang beragama Islam terdapat dua pengadilan yang berwenang menanganinya, yaitu Pengadilan Negeri dan Pengadilan Agama. Hal tersebut dapat terjadi, pertama, karena kedua-duanya sama-sama mengadili perkara perdata; Kedua, Pengadilan ditentukan sendiri oleh pemohon yang belum tentu memahami betul pengadilan mana yang berwenang untuk mengadili perkara yang ia ajukan. ${ }^{4}$

Berkaitan dengan latar belakang tersebut akan dilakukan kajian terhadap 2 (empat) Penetapan Pengadilan Permohonan Pengangkatan Anak, 1 (dua Penetapan Pengadilan Negeri, yaitu Penetapan Pengadilan Negeri Mojokerto Nomor 04/Pdt P/2012/PN Mkt serta Penetapan Pengadilan Agama Purwokerto Kedua Penetapan tersebut akan dikaji pertimbangan hukum hakim yang mengabulkan permohonan pengangkatan anak beserta kewenangannya masing-masing pengadilan dan akibat hukum dengan dikabulkannya permohonan pengangkatan anak.

\section{METODE PENELITIAN}

Penelitian atau kajian yang digunakan adalah penelitian hukum normatif dengan jenis penelitian kepustakaan. Penelitian hukum normatif adalah penelitian yang menggunakan data sekunder, ${ }^{5}$ dengan menggunakan pendekatan perundang-undangan dan regulasi yang bersangkut paut dengan isu hukum yang sedang ditangani dalam bahasa lain menurut Soetandyo merupakan tipe penelitian penemuan hukum in concreto terhadap penetapan

\footnotetext{
${ }^{3}$ M.Yahya Harahap, S.H, Hukum Acara Perdata, Sinar Grafika, Jakarta, 2008, h.181.

${ }^{4}$ Mukti Arto, Garis Batas Kekuasaan Pengadilan Agama dan Pengadilan Negeri”, Jurnal Varia Peradilan No 253 Tahun ke XXI Desember 2006 h. 16.

${ }^{5}$ Rony Hanitiyo Soemitro, 1994, Penelitian Hukum, Jakarta, Kencana, h. 133
} 
pengadilan tersebut. ${ }^{6}$ Data sekunder berupa penetapan pengadilan, peraturan perundang-undangan dan penelitian kepustakaan lainnya yang berkaitan dengan topik penelitian, dikumpulkan denganmetode dokumentasi. Data Penelitian dianalisis dengan analisa isi (content analysis)

\section{PEMBAHASAN}

Kompetensi Permohonan Pengangkatan Anak di Pengadilan Negeri dan Agama

Mengangkat anak (adopsi) adalah suatu perbuatan pengambilan anak orang lain ke pada keluarga sendiri, sehingga antara orang yang mengangkat anak dan anak yang diangkat itu timbul suatu hubungan kekeluargaan yang sama mirip korelasi antara orang tua dengan anak kandungnya sendiri. ${ }^{7}$ Iman Sudiyat berpendapat bahwa pengangkatan anak merupakan suatu perbuatan hukum mengangkat anak dari luar ke dalam kerabat. Sebagai akibatnya terjalin suatu ikatan sosial yang sama dengan ikatan biologisnya. $^{8}$ Sedangkan berdasarkan Soerjono Soekanto berpandangan bahwa pengangkatan anak ialah perbuatan mengangkat anak untuk dijadikan anaknya sendiri atau mengangkat seseorang pada kedudukan tertentu.

Dalam Kitab Undang-Undang Hukum Perdata (selanjutnya dianggap KUH Perdata) istilah adopsi tidak dikenal, sebab KUH Perdata memandang bahwa suatu perkawinan sebagai wujud hidup bersama bukan untuk memperoleh keturunan. Adopsi bias ditemui dalam hukum adat Indonesia asli juga bangsa Timur Asing Tionghoa. Pasal 261 dan Pasal 263 KUH Perdata menganut asas korelasi darah dimana dinyatakan bahwa yang bisa meneruskan keturunan merupakan anak sah.

${ }^{6}$ Soetandyo Wignjosoebroto, tanpa tahun, Hukum dan Metode Kajiannya, h 8.

${ }^{7}$ Wignjodiporo, 1995, Pengantar dan Asas-Asas Hukum Adat, Jakartra, Gunung Agung, h.15.

${ }^{8}$ Iman Sudiyat, 1990, Hukum Adat Sketsa Asas, Yogyakarta, Penerbit Liberty, h.102. 
Lembaga hukum adopsi golongan Timur Asing Tionghoa keberadaannya mempunyai hubungan dengan lembaga sosial penghormatan terhadap nenek moyang. Dimana yang harus melakukan penghormatan terhadap nenek moyang merupakan putera berdasarkan sistem clan yang patrilinial. menurut pasal 5-15 Stb. 1917 No. 129 mengatur bahwa:

a. Yang dapat mengadopsi adalah seorang pria Tionghoa baik beristri maupun pernah beristri yang tidak mempunyai putra atau belum mempunyai putra adopsi, maka ia mengangkat anak laki-laki menjadi putranya (lihat pasal 5 ayat (1)). Jadi yang dapat diadopsi hanyalah anak laki-laki saja.

b. Apabila yang mengangkat anak adalah seorang yang beristri, maka pengangkatan anak tersebut harus dilaksanakan bersamasama. Janda yang belum bersuami lagi, dapat mengadopsi anak laki-laki asal tidak dilarang/bertentangan testamen dari almarhum suami;

c. Yang diadopsi tidak boleh orang yang beristri dan tidak boleh anak yang telah diadopsioleh orang lain;

d. Perbedaan umur antara orang yang mengadopsi dengan anak yang di adopsi paling sedikit 18 tahun (kalau yang mengadopsi adalah orang laki-laki) atau 15 tahun kalau yang mengadopsi adalah janda;

e. Jika yang di adopsi itu seorang keluarga sedarah maka dengan dilakukannya adopsi, anak itu harus menduduki derajat keturunan yang sama terhadap keturunan yang sama dengan leluhur nya yang sama seperti sebelum diadopsi (pasal 7 ayat (2)).

Adopsi dalam hukum adat merupakan suatu perbuatan hukum untuk menjadikan anak orang lain sebagai anak kandung bagi orang tua angkatnya. dalam statusnya menjadi "anak kandung" setelah diadopsi, anak angkat tersebut memiliki beberapa hak serta kewajiban tertentu atas orang tua angkatnya.

Hak dan kewajiban tersebut meliputi hak-hak pada bidang hukum harta kekayaan. Sekalipun pengangkatan anak itu merupakan suatu perbuatan hukum pada bidang hukum 
kekeluargaan, akan tetapi akibat hukumnya juga berdampak pada bidang hukum harta kekayaan . Oleh sebab itu, di dalam hukum adat perbuatan hukum pengangkatan anak itu pada prinsipnya bukan hanya menjadi urusan dari pihak orang tua angkat (suami istri yang tidak mempunyai anak) itu saja, melainkan dia juga menjadi urusan kerabat atau anggota keluarga lainnya secara luas.

Pengangkatan anak dalam hukum adat sangat typical, dalam arti bahwa tidak adanya keseragaman tentang maksud dan dampak hukum dari perbuatan hukum tersebut. ${ }^{9}$ Pada sebagian masyarakat, pengangkatan anak tidak mempunyai maksud untuk mengakibatkan anak angkat itu menjadi anak kandung bagi orang tua angkatnya. Dimana hubungan hukum yang terdapat antara anak angkat dengan orang tua kandungnya tidak putus.

Dengan demikian anak angkat itu tidak kehilangan hak warisnya atas orang tua biologisnya. Sebaliknya, di sebagian warga yang lain, pengangkatan anak justru mengandung maksud untuk menjadikan anak orang lain sebagai anak kandung baginya. Sehingga korelasi hukum antara anak angkat itu harus diputuskan dari orang tua kandungnya sendiri. Kemudian, setelah itu anak adopsi berhak atas harta peninggalan orang tua angkatnya, dalam arti menjadi ahli waris. Selain itu, ada pula masyarakat tertentu yang adat istiadatnya tidak mengenal perbuatan hukum pengangkatan anak. $^{10}$

Pengangkatan anak dalam istilah Arab disebut tabanni, yaitu menjadikan seseorang sebagai anak. ${ }^{11}$ Al Qur'an menyebutnya da'iyyun, yaitu menghubungkan asal usul kepada seseorang yang bukan ayah kandungnya. Pengangkatan anak yang memutus hubungan hukum biologis anak tersebut dengan orang tua kandungnya hukumnya haram, dengan kata lain pengangkatan anak yang menjadikan anak

${ }^{9}$ Afdol, "Pengangkatan Anak dan Aspek Hukumnya Menurut Hukum Adat", Jurnal Suara Uldilag, Pokja Perdata Agama MARI, Jakarta Vol 3 No. XI September 2007, h.59.

${ }^{10}$ Iman Sudiyat, Op Cit h. 102.

${ }^{11}$ Rifyal Ka'bah, “Pengangkatan Anak Dalam UU No. 3 Tahun 2006 tentang Perubahan UU No.7 Tahun 1979 tentang Peradilan Agama dan akibatnya", Jurnal Varia Peradilan, MARI Tahun ke XXI No.248 Juli 2006, h.31.. 
itu sebagai anak kandung dilarang. Kebalikannya, pengangkatan anak yang bertujuan untuk membantu kesejahteraan anak sangat dianjurkan. $^{12}$

Pasal 171 (h) Kompilasi hukum Islam (KHI) mengatur pengangkatan anak menurut hukum Islam. "Anak angkat adalah anak yang dalam pemeliharaan hidupnya sehari-hari, biaya pendidikan dan sebagainya beralih tanggung jawabnya dari orang tua asal kepada orang tua angkatnya berdasarkan putusan pengadilan". Pengadilan yang dimaksud adalah Pengadilan Agama. Pasal 209 ayat (2) KHI menyatakan bahwa anak angkat hanya berhak mendapat washiah wajibah, sebanyak-banyaknya sepertiga dari harta warisan, bila almarhum tidak meninggalkan wasiat untuk anak angkatnya, tetapi tidak mendapatkan waris.

Undang-undang yang secara khusus mengatur tentang pengangkatan anak di Indonesia belum ada, akan tetapi secara sepintas diatur di berbagai peraturan perundangan, antara lain:

a. Undang-undang Nomor 4 Tahun 1979 tentang Kesejahteraan Anak

b. Undang-undang Nomor 35 Tahun 2014 tentang Perubahan atas Undang-undang Nomor 23 Tahun 2002 tentang Perlindungan Anak;

c. Undang-undang Nomor 23 Tahun 2006 Tentang Administrasi Kependudukan;

d. Surat Edaran Mahkamah Agung Nomor 2 Tahun 1979 Perihal Pengangkatan Anak;

e. Surat Edaran Mahkamah Agung Nomor 6 Tahun 1983 tentang Penyempurnaan SuratEdaran Nomor 2 Tahun 1979;

f. Surat Edaran Mahkamah Agung Nomor 4 Tahun 1989 tentang Pengangkatan Anak.

Kompetensi absolut merupakan kewenangan badan peradilan pada memeriksa jenis perkara tertentu yang secara mutlak tidak bisa diperiksa oleh badan pengadilan lain, baik pada lingkungan

${ }^{12}$ Tahir Azhary, "Anak Angkat dalam Perpektif Hukum Islam dan Kewenangan Perdilan Agama dalam hal Pengangkatan Anak", Jurnal Suara Uldilag, MARI, Vol; 3 No.XI September 2001, h. 1. 
pengadilan yang sama juga dalam lingkungan peradilan yang berbeda. Kompetensi absolut tersebut untuk menjawab pertanyaan apakah pengadilan tertentu (misalnya Pengadilan Negeri) berwenang memeriksa jenis perkara tertentu yang diajukan dan bukan pengadilan lain yang berwenang. Umumnya kompetensi absolut tergantung pada isi gugatan atau isi permohonan. Kompetensi mutlak ini disebut juga atribusi kekuasaan kehakiman.

Menurut Retnowulan Sutantio kompetensi absolut menyangkut pembagian kekuasaan antar badan peradilan dipandang dari macamnya pengadilan, menyangkut pemberian kekuasaan untuk mengadili. ${ }^{13}$ Dari segi kekuasaan absolut mengadili, kedudukan Pengadilan Negeri dapat diuraikan sebagai berikut:

a. Berdasarkan sistem pembagian lingkungan peradilan, pengadilan negeri berhadapan dengan kompetensi absolut peradilan lain, menyangkut kewenangan badan peradilan untuk memeriksa, mengadili dan memutus suatu perkara, berdasarkan pasal 18 Undang- undang Nomer 48 Tahun 2009 tentang Kekuasaan Kehakiman mengenal 4 (empat) lingkungan peradilan, yakni:

1. Kompetensi absolut dari Peradilan Umum adalah memeriksa, mengadili dan memutuskan perkara pidana yang dilakukan oleh orang-orang sipil dan perkara perdata, kecuali suatu peraturan perundang-undangan menentukan lain;

2. Kompetensi absolut dari Peradilan Agama adalah memeriksa, mengadili dan memutuskan perkara orang beragama islam dalam bidang perkawinan, warisan, wasiat, hibah, wakaf dan shadaqah;

3. Kompetensi absolut Peradilan Militer adalah memeriksa, mengadili dan memutus perkara pidana yang dilakukan oleh anggota militer, baik angkatan darat, angkatan laut maupun angkatan udara (Pasal 9 UU 37 Tahun 1997);

4. Kompetensi Peradilan Tata Usaha Negara adalah memeriksa,

${ }^{13}$ Retnowulan Sutantio, 1997, Hukum Acara Perdata Dalam Teori dan Praktek, Bandung, PT Mandar Maju. h. 11. 
mengadili dan memutus sengketa yang timbul dalam bidang tata usaha negara antara seseorang atau badanhukum perdata dengan badan atau pejabat tata usaha negara akibat dikeluarkannyasuatu keputusan tata usaha negara

b. Kewenangan absolut extra judicial berdasarkan yuridiksi khusus yang diatur dalam berbagai peraturan perundang-undangan, sistem dan badan yang bertindak melakukan penyelesaian itu disebut peradilan semu atau extra judicial.

Keempat lingkungan peradilan tersebut berada di bawah Mahkamah Agung yang merupakan penyelenggara kekuasaan kehakiman pada bidang yudikatif. Oleh karena itu, secara konstitusional bertindak menyelenggarakan peradilan, menegakkan hukum dan keadilan (to enforce the truth and justice) dalam kedudukannya sebagai pengadilan negara (state court) ${ }^{14}$

Metode untuk menentukan aktifitas administratif pengadilan dalam raealisasinya ada 2, yaitu metode enumeratif dan metode general. Metode enumeratif merupakan metode untuk menentukan kompetensi absolut pengadilan yang bersifat administratif yaitu dengan menyebutkan jenis-jenis objek sengketa yang menjadi wewenang pengadilan secara terperinci. Metode ini dibedakan menjadi dua, pertama metode enumeratif yang tertutup ialah metode yang ketat dengan menyebutkan secara detail dan limitatif berbagai jenis perkara yang dapat diajukan di pengadilan sehingga akan menutup kemungkinan berbagai jenis sengketa lainnya yang tidak disebutkan di dalam undang-undang. kedua, metode enurmeratif terbuka dimana bersifat lebih longgar, artinya sekalipun di dalam undang-undang secara detail disebutkan jenis-jenis sengketa yang dapat diajukan. Namun dimungkinkan bagi pengadilan untuk mengadili berbagai jenis sengketa lainnya yang belum atau tidak disebutkan dalam undang-undang.

Metode general merupakan metode untuk menentukan kompetensi absolut yang bersifat general. artinya, hanya merumuskan kriteria secara umum perihal objek sengketa yang

${ }^{14}$ Yahya Harahap, 2005, Hukum Acara Perdata, Jakarta, Sinar Grafika.h.

181. 
menjadi wewenang suatu pengadilan tanpa menyebutkan secara detail jenis-jenis sengketa yang terdapat dalam undang-undang. Dalam metode ini terdapat kriteria yang dipergunakan, yaitu:

a. Kriteria Objek, untuk menentukan suatu jenis perkara itu masuk dalam kompetensi absolut peradilan tertentu dengan mendasarkan pada kriteria objek sengketa atau jenis perkaranya;

b. Kriteria Subjek menggunakan kriteria salah satu subjek yang bersengketa, misal apabila salah satu pihak adalah badan atau pejabat administrasi negara, maka sengketa itu menjadi kewenangan peradilan administrasi;

c. Kriteria Subjek dan Objek yaitu menggunakan dua kriteria, yaitu subjek dan objek berkaitan dengan unsur hukum publik dan hukum privat atau badan hukum publik atau bukan.

Sebelum disahkannya Undang-Undang Nomor 3 Tahun 2006, beberapa Pengadilan Agama telah membuat penetapan pengangkatan anak berdasarkan hukum Islam. Dalam Pertimbangan Hakim pada Penetapan No.011/Pdt. P/2001/PA. Bn (Bengkulu) dinyatakan bahwa "para Pemohon telah memenuhi maksud dan unsur-unsur Pasal 49 ayat (1) huruf b UU No. 7 Tahun1989, Pasal 171 huruf (h), dan Pasal 200 KHI. Pasal 7 ayat (1) Peraturan Menteri Agama No.2 Tahun 1987, serta fatwa MUI No-U-335/MUI/VI/182/tanggal 18 Sya'ban 1402/10 Juni 1982, maka Majelis Hakim berpendapat bahwa permohonan para Pemohon untuk mengangkat anak/bayi yang kemudian diberi nama M Huda Putra Nugraha dapat dikabulkan", sebelum itu di dalam pertimbangan hukum telah ditegaskan bahwa:

1. Islam membolehkan pengangkatan anak dengan tujuan memelihara kepentingan anak;

2. Pengangkatan anak dalam Islam sebenarnya hanya peralihan tanggung jawab pemeliharaan biaya hidup, pendidikan, bimbingan agama, dan lain-lain dari orang tua asal kepada orang tua angkat, tetapi tidak memutus hubungan hukum. nasab dengan orang tua asalnya;

3. Antara anak angkat dan orang tua angkat terdapat hubungan keperdataan washiah wajibah; 
4. Untuk pengangkatan anak diperlukan persetujuan orang tua asal, wali, atau badan hukum yang menguasai anak yang akan diangkat;

Pertimbangan majelis hakim Pengadilan Agama Bantul dalam Penetapan nya No.06/ Pdt.P/2006/PA.Btl. “bahwa pengangkatan anak tidak memutuskan atau merubah nasab antara anak angkat dengan orang tua sal sehingga karenanya anak tersebut tetap dinasabkan kepadaorang tua kandungnya berdasarkan Pasal 43 (1) UU No. 1 Tahun 1974 jo Pasal 100 KHI Tahun 1991 serta petunjuk Allah dalam al-Qur' an surah al-Ahzab ayat 5.

\section{Pertimbangan Hukum Hakim Permohonan Pengangkatan Anak di Pengadilan Negeri dan Agama}

Berdasarkan data yang mengacu pada Penetapan Pengadilan Negeri dan Penetapan Pengadilan Agama dapat dikemukakan sebagai berikut:

Pertama, Penetapan Pengadilan Negeri Mojokerto Nomor: 04/Pdt.P/2012/PN.Mkt, tanggal 17 Januari 2012, Majelis Hakim dalam pertimbangan nya melihat pada subjek pemohon pengangkatan anak bertempat tinggal di wilayah Pengadilan Negeri Mojokerto, maka Pengadilan Negeri memiliki wewewnang untuk memeriksa dan mengadili permohonan perkara, dilihat dari subjek dari pemohon berdomisili, bukan subjek calon anak yang akan diangkat, karena calon anak yang akan diangkat kelahiran Surabaya yang setelah itu berada dalam pengasuhan Dinas Sosial Kabupaten Sidoarjo. Pertimbangan Majelis hakim tersebut tidak sesuai dengan penjelasan pengertian domisili menurut SEMA No. 6 Tahun 1983 yang menyatakan bahwa permohonan/ pengesahan pengangkatan anak hendaknya ditujukan kepada ketua Pengadilan Negeri yang wilayah hukumnya meliputi rumah atau wilayah domisili anak yang akan diangkat.

Landasan hukum yang digunakan majelis hakim karena Pemohon memilih untuk diperiksa dan diputus di Pengadilan Negeri Mojokerto, hal ini yang dijadikan dasar majelis hakim 
Dualisme Kompetensi Peradilan Permohonan Pengangkatan Anak Bagi Pemohon Yang Beragama Islam

menerima untuk kemudian memeriksa dan memutus permohonan pengangkatan anak. Majelis Hakim mengabaikan asas personalitas keislaman karena pemohon beragama Islam dan calon anak angkat juga beragama Islam.

Sebagaimana dikemukakan oleh Mukti Arto bahwa asas personalitas keislaman adalah asas yang memberlakukan hukum Islam terhadap seorang muslim. Pertimbangan hukum majelis berdasarkan pada SEMA No. 2 tahun 1979 jo SEMA No. 6 tahun 1983 jo SEMA No. 4 tahun 1989 jo SEMA No. 2 tahun 2009, PP RI No. 54 tahun 1987, Pasal 39 ayat (1) UU No. 23 tahun 2002. Dalam pasal 39 ayat (1) tersebut dinyatakan bahwa ketentuan pengangkatan anak hanya bisa dilakukan demi kebaikan anak dan dilakukan berdasarkan adat kebiasaan setempat dan peraturan perundangundangan yang ada. Hal inilah yang mendasari pertimbangan majelis hakim pada adat kebiasaan lokal dan ketentuan undangundang yang berlaku, bukan pada agama subjek pemohon dan subjek calon anak angkat. Maka dari itu dalak amar majlis hakim dinyatakan bahwa majelis hakim mengabulkan permohonan Pemohon, menyatakan pengangkatan anak yang dilakukan pemohon sah berdasarkan hukum, memerintahkan kepada Panitera Pengadilan Negeri Mojokerto atau Pejabat yang ditunjuk itu, untuk mengirimkan salinan penetapan Pengadilan Negeri yang ditunjuk itu, untuk mengirimkan salinan penetapan Pengadilan Negeri yang telah mempunyai kekuatan hukum tetap pada Dinas Kependudukan serta Catatan Sipil Kabupaten Mojokerto agar pengadopsian anak oleh para pemohon tersebut dicantumkan di sisi pinggir dari Akta Kelahiran.

Kedua, Penetapan Pengadilan Agama Purwokerto Nomor 130/Pdt.P/2014/PA Pwt. Tentang pengangkatan anak mengacu pada ketentuan pasal 49 huruf (a) nomor 11 UU Nomor 3 Tahun 2006, tentang Peradilan Agama, bahwa Pengadilan agama memiliki kewenangan absolut memeriksa dan menetapkan pengangkatan anak, tidaklah tepat seharusnya pasal 49 huruf a angka 20, dalam bidang Perkawinan, dalam bidang Perkawinan Pengadilan Agama 
Dualisme Kompetensi Peradilan Permohonan Pengangkatan Anak Bagi Pemohon Yang Beragama Islam

berwenang mengeluarkan penetapan asal-usul seorang anak dan pengangkatan anak berdasarkan hukum Islam.

Kemudian pemohon dan calon anak angkat beragama Islam beragama Islam dan berdomisili di wilayah Pengadilan agama Purwokerto. Di samping itu majelis hakim juga mendasarkan pada pasal 171 huruf (h) KHI. Berdasarkan ketentuan tersebut majelis hakim mempertimbangkan akibat hukumnya bahwa pengangkatan anak tidak memutuskan hubungan darah antara anak dengan orang tua biologisnya. Bagi anak perempuan yang menjadi wali nikahnya adalah ayah kandung. Pengangkatan anak tidak berakibat pada hak kewarisan dan akibat hukum lainnya.

Majelis Hakim juga memberikan pertimbangan berdasarkan syariat Islam, ketentuan pasal 39 UU No. 23 tahun 2003, SEMA No. 2/1979, SEMA No. 6/1983, SEMA No 3 Tahun 2005 tentang Pengangkatan Anak serta Peraturan Menteri Sosial No.130/HUK/2009, UU No.7/1989 menentukan bahwa hukum acara yang berlaku pada Peradilan Agama adalah hukum acara perdata yang berlaku pada Peradilan Negeri.

Tabel 1. Akibat Hukum Pengangkatan Anak di Pengadilan

Negeri dan Pengadilan Agama

\begin{tabular}{|c|l|l|l|}
\hline No. & Unsur Nilai & \multicolumn{1}{|c|}{ Penetapan PN } & \multicolumn{1}{|c|}{ Penetapan PA } \\
\hline 1. & Nasab & $\begin{array}{l}\text { Anak angkat } \\
\text { terputus dengan } \\
\text { nasab, dan } \\
\text { dinasabkan kepada } \\
\text { orang tua angkatnya }\end{array}$ & $\begin{array}{l}\text { Anak angkat tidak } \\
\text { terputus dengan } \\
\text { nasab orang tua } \\
\text { kandungnya, yang } \\
\text { beralih hanyalah } \\
\text { tanggung jawab dari } \\
\text { orang tua kandung } \\
\text { kepada orang tua } \\
\text { angkat }\end{array}$ \\
\hline 2. & Panggilan & $\begin{array}{l}\text { Anak angkat } \\
\text { dipanggil (Bin/Binti) } \\
\text { dengannama ayah }\end{array}$ & $\begin{array}{l}\text { Anak angkat } \\
\text { dipanggil } \\
\text { (Bin/Binti) dengan }\end{array}$ \\
\hline
\end{tabular}


Dualisme Kompetensi Peradilan Permohonan Pengangkatan Anak Bagi Pemohon Yang

\begin{tabular}{|c|c|c|c|}
\hline & & $\begin{array}{l}\text { atau orang tua } \\
\text { angkatnya }\end{array}$ & $\begin{array}{l}\text { namaayah atau } \\
\text { orang tua } \\
\text { kandungnya }\end{array}$ \\
\hline 3. & Perwalian & $\begin{array}{l}\text { Orang tua menjadi } \\
\text { wali penuh terhadap } \\
\text { anakangkatnya, } \\
\text { termasuk menjadi } \\
\text { wali nikah, jikaanak } \\
\text { angkat perempuan }\end{array}$ & $\begin{array}{l}\text { Orang tua angkat } \\
\text { tidak sah menjadi } \\
\text { wali nikahanak } \\
\text { angkatnya, jika } \\
\text { anak angkat } \\
\text { perempuan }\end{array}$ \\
\hline 4. & Hak Waris & $\begin{array}{l}\text { Anak angkat } \\
\text { memiliki hak waris } \\
\text { sebagaimanahak } \\
\text { waris yang dimiliki } \\
\text { anak kandung, dapat } \\
\text { menghabiskan } \\
\text { seluruh harta warisan } \\
\text { orang tuaangkatnya } \\
\text { dan juga } \\
\text { menggugurkan } \\
\text { orang tusdan } \\
\text { saudara kandung } \\
\text { orang tua angkat, } \\
\text { jika orang tua angkat } \\
\text { tidak memiliki anak }\end{array}$ & $\begin{array}{l}\text { Anak angkat tidak } \\
\text { menjadi ahli waris } \\
\text { dari orangtua } \\
\text { angkatnya. Anak } \\
\text { angkat dapat } \\
\text { memperoleh harta } \\
\text { warisan orang tua } \\
\text { angkatnya melalui } \\
\text { lembaga wasiat } \\
\text { wajibah yang } \\
\text { jumlahnya tidak } \\
\text { boleh melebihi } \\
\text { sepertiga harta } \\
\text { warisan }\end{array}$ \\
\hline 5. & $\begin{array}{l}\text { Mahrom } \\
\text { Kawin }\end{array}$ & $\begin{array}{l}\text { Anak angkat tidak } \\
\text { sah dinikahi oleh } \\
\text { orangtua angkatnya }\end{array}$ & $\begin{array}{l}\text { Anak angkat } \\
\text { boleh dinikahi } \\
\text { orang tua } \\
\text { angkatnya }\end{array}$ \\
\hline
\end{tabular}




\begin{tabular}{|c|c|c|c|}
\hline 6. & $\begin{array}{l}\text { Status anak } \\
\text { angkat bukan } \\
\text { dengan } \\
\text { status orang } \\
\text { mengangkat }\end{array}$ & $\begin{array}{l}\text { Apabila orang tua } \\
\text { angkatnya seorang } \\
\text { laki-lakiyang telah } \\
\text { kawin, maka anak } \\
\text { angkat tersebut } \\
\text { dianggap sebagai } \\
\text { anak yang dilahirkan } \\
\text { dari perkawinan } \\
\text { mereka. Apabila } \\
\text { perkawinan ayah } \\
\text { angkatnya telah } \\
\text { putus, maka anak } \\
\text { angkat dianggap } \\
\text { sebagai anak yang } \\
\text { lahir dari } \\
\text { perkawinan mereka } \\
\text { yang putus karena } \\
\text { kematian. Apabila } \\
\text { seorang janda, maka } \\
\text { anak angkat harus } \\
\text { dianggap di lahirkan } \\
\text { dari perkawinannya } \\
\text { dengan suami yang } \\
\text { telah meninggal } \\
\text { dunia }\end{array}$ & $\begin{array}{l}\text { Hukum Islam } \\
\text { melarang } \\
\text { ketentuan- } \\
\text { ketentuantersebut }\end{array}$ \\
\hline
\end{tabular}

\section{Akibat Hukum Permohonan Pengangkatan Anak Di Pengadilan Negeri DanPengadilan Agama}

Prinsip pengangkatan anak adalah adanya perlindungan anak tersebut, salah satu perlindungan hukum berupa kedudukan anak angkat dalam mewaris, misalnya kedudukan anak angkat sama dengan kedudukan anak kandung yang akan menjadi penerus dan menjadi ahli waris dari orang tua angkatnya. Kedudukan anak angkat dalam hukum adat sangat erat kaitannya dengan struktur 
tradisional masyarakat hukum adat setempat berdasarkan sistem kekerabatan patrilinial, matrilinial atau parental. ${ }^{15}$ Berbagai berbentuk adopsi yang dikenal di Indonesia mempunyai akibat hukum yang berbeda-beda antara daerah yang satu dengan yang lain. ${ }^{16}$ Demikian pula akibat hukum pengangkatan anak yang dilakukan di PengadilanNegeri dan di Pengadilan Agama.

Pengangkatan anak di Pengadilan Agama, berdasarkan Pasal 171 huruf (h), berdasarkan hukum Islam maka dalam pengangkatan anak berlaku ketentuan: pengangkatan anak dalam syariat Islam dibolehkan sepanjang motivasi nya mengutamakan kepentingan anak, dalam pengangkatan anak tanggung jawab pemeliharaan untuk hidup sehari-hari beralih dari orang tua asal, pengangkatan anak tidak memutuskan hubungan darah, tidak demikian Dengan pengangkatan anak di Pengadilan Negeri, akibatnya lebih dari yang terdapat di Pengadilan Agama, karena anak angkat mewaris dari orang tua angkatnya, bahkan dalam hukum adat di Jawa, anak angkat berhak mewaris dari dua sumber yang dikenal dengan istilah "ngangsu sumur loro" Untuk jelas nya kita lihat berikut ini:

\section{PENUTUP}

\section{Kesimpulan}

1. Kompetensi permohonan pengangkatan anak bagi pemohon dan calon anak angkat yang beragama Islam berada pada dua pengadilan, yaitu Pengadilan Negeri dan Pengadilan Agama;

2. Pertimbangan hukum hakim pengangkatan anak pada Penetapan Pengadilan Negeri mendasarkan pada Pasal 39 ayat (1) UU No.23 Tahun 2001 jo UU Nomor 35 Tahun 2014 Tentang Perlindungan Anak, Pasal 47 UU Nomor 23 tahun 2006 tentang Administrasi Kependudukan, Pasal 2, Pasal 3 ayat (2), Pasal 9 ayat (2), pasal 10 ayat (2), pasal 12 ayat (1), Pasal 13 Peraturan Pemerintah Nomor

\footnotetext{
${ }^{15}$ Endang Sumiarni, 2000, Perlindungan Hukum Terhadap Anak dalam hukum Keluarga, Universitas Atmajaya,Yogyakarta, h.6.

${ }^{16}$ Muderis Zaini, 1995, Adopsi, Suatu Tinjauan dari Tiga Sistem Hukum, Sinar Grafika, Jakarta,h.23
} 
54 tahun 2007 tentang Pelaksanaan Pengangkatan Anak, SEMA No 6 Tahun 1983, sedangkan Pertimbangan hukum hakim pada Penetapan Pengadilan Agama mendasarkan pada penjelasan pasal 49 huruf (a) angka 20 UU No. 3 Tahun 2006 tentang Peradilan Agama, Pasal 171 huruf (h) KompilasiHukum Islam;

3. Akibat hukum pengangkatan anak melalui Pengadilan Negeri anak angkat mempunyai hak waris dari orang tua angkatnya seperti anak kandung, sedangkan pengangkatan Anak melalui Pengadilan Agama anak angkat tidak mempunyai hak waris dari orang tua angkatnya, karena anak angkat tidak terputus hubungan darah dengan orang tua kandungnya. Pengangkatan anak dalam hukum Islam adalah anak yang dalam pemeliharaan untuk hidupnya sehari-hari, biaya pendidikan dan sebagainya beralih tanggung jawabnya dari orang tua asal kepada orang tua angkatnya berdasarkan Putusan Pengadilan.

\section{DAFTAR PUSTAKA}

Abdoellah, Priyatmanto. Revitalisasi Kewenangan PTUN, Yogyakarta, Cahaya AtmaPustaka. 2016.

Afdol, "Pengangkatan Anak dan Aspeknya Menurut Hukum Adat", Jurnal Suara Uldilag, PokjaPerdata MARI, Jakarta, Vol 3 No.XI September 2007

Arto, Mukti, “Garis batas kekuasaan Pengadilan Agama dan

Pengadilan Negeri", Jurnal VariaPeradilan, IKAHI, Jakarta

No.253 Tahun Ke- XXI Bulan Desember 2006

Azhari, Tahir, "Anak Angkat dalam Perpektif Hukum Islam dan Kewenangan Pengadilan Agama Dalam Pengangkatan Anak", Jurnal Uldilag, Jakarta Vol 3 No.XI September 2007

Fauzan, “Perbedaan Mendasar Akibat Hukum Penetapan Pengangkatan Anak di Pengadilan Negeri dan Pengadilan Agama", Jurnal Varia Peradilan, Jakarta, Tahun XXII No. 256 Maret 2007 
Dualisme Kompetensi Peradilan Permohonan Pengangkatan Anak Bagi Pemohon Yang Beragama Islam

Harahap, Yahya, Hukum Acara Perdata Tentang Gugatan, Persidangan,Penyitaan, Pembuktian dan Putusan Pengadilan, Jakarta, Sinar Grafika. 2005.

Kabah, Rifyal, “Pengangkatan Anak Dalam Undang-Undang No 3 Tahun 2006 Tentang Peradilan Agama dan akibatnya", Jurnal Varia Peradilan, IHAHI, Tahun ke XXI No. 248Juli 2006

Mahmud Marzuki, Peter. Penelitian Hukum. Jakarta, Penerbit Kencana Mertokusumo. , 2013.

Sudikno. Hukum Acara Perdata Indonesia. Yogyakarta Penerbit Liberty. 2010.

Sumiarni, Endang. Perlindungan Hukum Terhadap Anak Dalam Hukum Keluarga. Yogyakarta, Atmajaya. 2000.

Sudiyat, Iman. Hukum Adat Sketsa Asas, Yogyakarta, Penerbit Liberty Sutantio. 1990.

Retnowulan. Hukum Acara Perdata Dalam Teori Dan Praktik. Bandung, PT MndarMaju. 1997.

Soekanto, Soerjono. Intisari Hukum Keluarga. Bandung, Penerbit Alumni . 1980.

Subekti, Iman Winarsih, “Pengaturan dan Akibat Hukum Pengangkatan Anak Menurut Hukum Perdata", Jurnal Suara Uldilag, Pokja Perdata Agama Vol 3No. XI, September 2007

Undang-Undang Tentang Perlindungan Anak, UU No.23 Tahun 2002,

LN No 109 Tahun 2002 TLN No. 4235

Undang-Undang Administrasi Kependudukan, UU No. 23 Tahun 2006. LN No124 Tahun 2006TLN No.4674

Undang-Undang Kekuasaan Kehakiman UU No. 48 Tahun 2009 LN No. 157 Tahun 2009 TLN5976.

Wignjodippuro. Pengantar dan Asas-Asas Hukum Adat. Jakarta Gunung Agung. 1995 
Dualisme Kompetensi Peradilan Permohonan Pengangkatan Anak Bagi Pemohon Yang Beragama Islam 